\title{
Advances on Antiviral Activity of Morus spp. Plant Extracts: Human Coronavirus and Virus-Related Respiratory Tract Infections in the Spotlight
}

\author{
Inès Thabti ${ }^{1,2}$, Quentin Albert ${ }^{1}{ }^{\circledR}$, Stéphanie Philippot ${ }^{1}$, François Dupire ${ }^{1}{ }^{(0)}$, \\ Brenda Westerhuis ${ }^{3,4}$, Stéphane Fontanay ${ }^{1,5}$ (D) Arnaud Risler ${ }^{1}$, Thomas Kassab ${ }^{1}$, \\ Walid Elfalleh ${ }^{2,6} \mathbb{D}^{\mathbb{D}}$, Ali Aferchichi ${ }^{2}$ and Mihayl Varbanov ${ }^{1, *}$ \\ 1 L2CM, Université de Lorraine, CNRS, F-54000 Nancy, France; thabtiines@yahoo.fr (I.T.); \\ quentin.albert@univ-lorraine.fr (Q.A.); stephanie.philippot@univ-lorraine.fr (S.P.); \\ francois.dupire@univ-lorraine.fr (F.D.); stephane.fontanay@univ-lyon1.fr (S.F.); \\ arnaud.risler@univ-lorraine.fr (A.R.); thomas.kassab@me.com (T.K.) \\ 2 Laboratoire d'Aridoculture et Cultures Oasiennes, Institut des régions Arides de Médenine, Route el Djorf, \\ Médenine 4119, Tunisia; walid.elfalleh@fst.rnu.tn (W.E.); ferchichi.ali1@yahoo.fr (A.A.) \\ 3 Department of Medical Microbiology, Academic Medical Center, Meibergdreef 15, 1105 AZ Amsterdam, \\ The Netherlands; b.westerhuis@erasmusmc.nl \\ 4 Department of Viroscience, Erasmus MC, 3015 GD Rotterdam, The Netherlands \\ 5 INSA de Lyon, Université de Lyon, CNRS, UMR5240, F-69622 Villeurbanne, France \\ 6 Energy, Water, Environment and Process Laboratory, (LR18ES35), National Engineering School of Gabes, \\ University of Gabes, Gabes 6072, Tunisia \\ * Correspondence: mihayl.varbanov@univ-lorraine.fr
}

Academic Editors: Patrícia Rijo, Vera Isca and Daniele Passarella

Received: 20 March 2020; Accepted: 15 April 2020; Published: 18 April 2020

\begin{abstract}
Background: Viral respiratory infections cause life-threatening diseases in millions of people worldwide every year. Human coronavirus and several picornaviruses are responsible for worldwide epidemic outbreaks, thus representing a heavy burden to their hosts. In the absence of specific treatments for human viral infections, natural products offer an alternative in terms of innovative drug therapies. (2) Methods: We analyzed the antiviral properties of the leaves and stem bark of the mulberry tree (Morus spp.). We compared the antiviral activity of Morus spp. on enveloped and nonenveloped viral pathogens, such as human coronavirus (HCoV 229E) and different members of the Picornaviridae family-human poliovirus 1, human parechovirus 1 and 3, and human echovirus 11. The antiviral activity of 12 water and water-alcohol plant extracts of the leaves and stem bark of three different species of mulberry-Morus alba var. alba, Morus alba var. rosa, and Morus rubra-were evaluated. We also evaluated the antiviral activities of kuwanon G against HCoV-229E. (3) Results: Our results showed that several extracts reduced the viral titer and cytopathogenic effects (CPE). Leaves' water-alcohol extracts exhibited maximum antiviral activity on human coronavirus, while stem bark and leaves' water and water-alcohol extracts were the most effective on picornaviruses. (4) Conclusions: The analysis of the antiviral activities of Morus spp. offer promising applications in antiviral strategies.
\end{abstract}

Keywords: Morus spp.; human coronavirus; respiratory viruses; picornaviruses; crude extract; antiviral activities

\section{Introduction}

The last decades have seen the lack of new therapeutic drug developments against infectious diseases. Thus, emergence of several resistances and new epidemics are more and more noticed all 
over the world. These public health concerns have led to (re)evaluating traditional medical practices in order to highlight new molecules or new mechanisms of action. Plants like Morus spp., jackfruit (Artocarpus heterophyllus), coffea, and others are more and more studied in this context. Their potential activity against viral infections have been previously described in several studies [1-4].

Viral respiratory infections cause life-threatening diseases in millions of people worldwide every year. Human coronaviruses and several picornaviruses are responsible for regular worldwide epidemic outbreaks, thus representing a growing global public health problem. For instance, picornavirus infections are the most common infections identified in patients of all ages, and during peak season, picornaviruses cause $82 \%$ of all episodes of acute nasopharyngitis [5,6]. Among these viruses, enteroviruses like poliovirus 1 (PV1), human echoviruses, and parechoviruses share common features-they are small (20-30 nm), nonenveloped, positive single-stranded RNA viruses, causing mild respiratory diseases; however, HPeV type 1 and 3 (HPeV1 and 3) and echovirus 11 (Echo 11) can cause severe systemic diseases in young infants [7]. Structurally different, human coronaviruses (HCoVs) are bigger (120-160 nm), enveloped, positive single-stranded RNA viruses responsible for a large portion of upper and mild respiratory tract infections, like the common cold, bronchitis, or pneumonia. They have been isolated worldwide. Most established coronaviruses exhibit winter seasonality, with global geographical distributions of the documented cases [8]. They also can be severe and deadly for newborns, young infants, elderly, or immunosuppressed patients and can be associated with high rates of mortality. Indeed, no treatments, nor vaccines, are available against $\mathrm{HCoVs}$, and the existing treatments are essentially symptomatic. Few new molecules show an interest in this context (i.e., glycyrrhizin and nelfivanir) [9-11].

The lack of specific treatment and the emergence of several and recent pandemics due to coronaviruses like SARS (severe acute respiratory syndrome, 2002-2003) and MERS (Middle East respiratory syndrome coronavirus, 2012), as the actual epidemic started in China (December, 2019), where a new $\mathrm{HCoV}$ is emerging (2019-nCov, then renamed SARS-CoV-2 [12]), underline the strong need of further investigations in the physiopathology and treatments of such pathologies $[11,13]$.

The development of research fields like ethnopharmacology highlight the interest in traditional medical practices. In this context, Morus species have been reported for their medicinal uses in many regions of the world. Its antibacterial and antifungal activities have been previously studied [14-16]. The genus Morus, which belongs to the family Moraceae, counts 24 species with at least 100 varieties. The origins of Morus spp. are believed to be in Asia, but the plant has spread all over the world, and it can now grow from temperate to subtropical regions. Its growth does not require specific soil properties $[17,18]$.

For centuries, Asian populations, especially Chinese populations, traditionally used Morus spp. against fever, sore throat, to protect the liver, enhance eyesight, rheumatism, diuresis, and blood pressure $[18,19]$. Consequently, the different parts of the plant have been studied for potential biological activities $[14,15,18,19]$. Several chemical families have been isolated in Morus species, like flavonoids, benzofurans, stilbene, polyhydroxylated alkaloids, and kuwanons, showing a large variety of pharmacological activities. For example, flavonoids and oxyresveratrol showed anti-inflammatory activities, while mulberrofuran showed antibacterial activities against pathogens like Staphylococcus aureus. The group of kuwanons (isoprenylated flavonoids) include various compounds like kuwanon C, E, G, H, J, and S, which exhibit distinct biological activities. Indeed, kuwanon G showed antibacterial activities against Streptococcus mutans and methicillin-resistant Staphylococcus aureus at $12 \mu \mathrm{g} / \mathrm{mL}$ (minimal inhibition concentration) [20]. Kuwanon C has shown an antifungal activity against Candida albicans and Saccharomyces cerevisiae [16].

Studies exploring the antiviral activities of Morus extracts are less numerous despite a confirmed potential. Indeed, mulberry juice reduces the cytopathogenic effect of murine norovirus 1 (MNV-1) and feline calicivirus FCV-F9 [15]. Arylbenzofurans extracted from Morus cortex are described like replication inhibitors of the hepatitis $\mathrm{C}$ virus (HCV) [15]. Scientific literature also describes kuwanons (among others chemical structures found in Morus spp.) as potentially antiviral. Indeed, the authors 
of [16] reported kuwanon $\mathrm{H}$ as a human immunodeficiency virus (HIV) inhibitor, leachianone as a human simplex virus 1 and 2 (HSV 1 and 2) inhibitor, and three flavonoids as influenza, respiratory syncytial virus (RSV), and adenoviruses inhibitors [1,4]. Other kuwanons, like kuwanon G, a prenylated flavon, have been studied for several biological properties, like anti-inflammation activity, anti-oxidant, and antibacterial activities [21]. Though the bioactivity of kuwanon G is evident, no antiviral activity has yet been described for this compound.

In this context, Morus species show a good pharmacological potential against several pathologies, including emerging viruses. Considering the needs of new therapeutic strategies against pathogenic respiratory viruses like coronaviruses and picornaviruses, this study proposes to evaluate the potential activity of aqueous and hydromethanolic extracts from the stem barks and leaves of three different species of mulberry-Morus alba var. alba, Morus alba var. rosa, and Morus rubra on human coronavirus 229E and four different members of the Picornaviridae family-human poliovirus 1, human parechovirus 1 and 3, and human echovirus 11. The study was further extended to the analysis of the phytochemistry profiles of the plants by gas chromatography coupled with mass spectrometry (GC-MS) and liquid chromatography coupled with mass spectrometry (LC-MS) and the quantitative investigation by GC-MS.

\section{Results}

\subsection{Mass Spectrometry Characterisation of Morus spp. Extracts}

In this study, we achieved the characterization of various compounds, like flavonoids and other phenolic components extracted from lyophilized mulberry leaves and stem barks, from water and hydroalcohol extracts. Identification of mulberry leaves and stem bark constituents was carried out on the basis of the complementary information obtained from high-resolution mass spectrometry (ESI/QTOF). To the best of our knowledge, the list of the identified compounds is consistent with the one reported in the literature in the three cultivars analyzed. Our HRMS analysis revealed the presence of different polyphenolic compounds in the extracts, with coumarins, tannins, triterpenes, and flavonoids being the major ones. We further identified specific compounds found in the majority and in the most effective antiviral extracts, such as alkaloids (1-deoxynojirimycin), prenylated flavonoids (kuwanon G), and stilbenoids (mulberroside A).

\subsection{Cytotoxicity Assays}

The results of in vitro cytotoxicity of the aqueous and hydromethanolic extracts are presented in Table 1. For hydromethanolic stem barks extracts, the CC50 ranged from $162.33 \mu \mathrm{g} / \mathrm{mL}$ (for M. rubra extract) to $253.33 \mu \mathrm{g} / \mathrm{mL}$ (for M. alba var. alba extract). For hydromethanolic leaves' extracts, the CC50 ranged, respectively, from $908.20 \mu \mathrm{g} / \mathrm{mL}$ (for $M$. alba var. rosea extract) to $1051.66 \mu \mathrm{g} / \mathrm{mL}$ (for $M$. rubra extract). Aqueous stem barks' extracts had CC50 ranged between $3166.00 \mu \mathrm{g} / \mathrm{mL}$ (for M. alba var. rosea extract) to $4330.33 \mu \mathrm{g} / \mathrm{mL}$ (for M. alba var. alba extract). Finally, leaves' aqueous extracts of the three studied taxa had the same CC50 values, $>5000 \mu \mathrm{g} / \mathrm{mL}$.

Overall, hydromethanolic stem barks' extracts were the most cytotoxic (mean $=197.77 \pm$ $48.77 \mu \mathrm{g} / \mathrm{mL})$, while aqueous leaves' extracts are the less cytotoxic $(>5000.00 \mu \mathrm{g} / \mathrm{mL})$.

Figure 1 presents the cytotoxic effects of kuwanon G on L-132 cells and revealed that a concentration of $5 \mu \mathrm{g} / \mathrm{mL}$ does not induce a decrease in cell viability (99.19\% compared to the control). However, cells viability decreases for higher concentrations and reaches $50 \%$ for a concentration estimated at $12 \mu \mathrm{g} / \mathrm{mL}$. 
Table 1. In vitro cytotoxic activity of stem barks and leaves' aqueous and hydromethanolic extracts on L-132 cells. Experiments were performed in triplicate, and the results are representative of three independent experiments.

\begin{tabular}{|c|c|c|c|}
\hline \multirow{2}{*}{\multicolumn{2}{|c|}{ Vegetal Material }} & \multirow{2}{*}{ Extract } & \multirow{2}{*}{$\frac{\mathrm{CC}_{50}(\mu \mathrm{g} / \mathrm{mL}) \pm \mathrm{SD}}{\mathrm{L}-132}$} \\
\hline & & & \\
\hline \multirow{6}{*}{ Stem barks } & \multirow{2}{*}{ M. alba var. alba } & $\mathrm{MeOH}$ & $253.33 \pm 14.57$ \\
\hline & & $\mathrm{Aq}$ & $4330.33 \pm 629.77$ \\
\hline & \multirow{2}{*}{ M. alba var. rosea } & $\mathrm{MeOH}$ & $178.00 \pm 11.00$ \\
\hline & & $\mathrm{Aq}$ & $3166.00 \pm 671.63$ \\
\hline & \multirow{2}{*}{ M. rubra } & $\mathrm{MeOH}$ & $162.33 \pm 8.50$ \\
\hline & & $\mathrm{Aq}$ & $3192.00 \pm 885.91$ \\
\hline \multirow{6}{*}{ Leaves } & \multirow{2}{*}{ M. alba var. alba } & $\mathrm{MeOH}$ & $1034.15 \pm 225.83$ \\
\hline & & $\mathrm{Aq}$ & $>5000$ \\
\hline & \multirow[b]{2}{*}{ M. alba var. rosea } & $\mathrm{MeOH}$ & $908.20 \pm 66.53$ \\
\hline & & $\mathrm{Aq}$ & $>5000$ \\
\hline & \multirow{2}{*}{ M. rubra } & $\mathrm{MeOH}$ & $1051.66 \pm 207.76$ \\
\hline & & $\mathrm{Aq}$ & $>5000$ \\
\hline
\end{tabular}

MeOH: hydromethanolic extract; Aq: aqueous extract. Each value in the table is represented as mean $\pm \mathrm{SD}(\mathrm{n}=3)$.

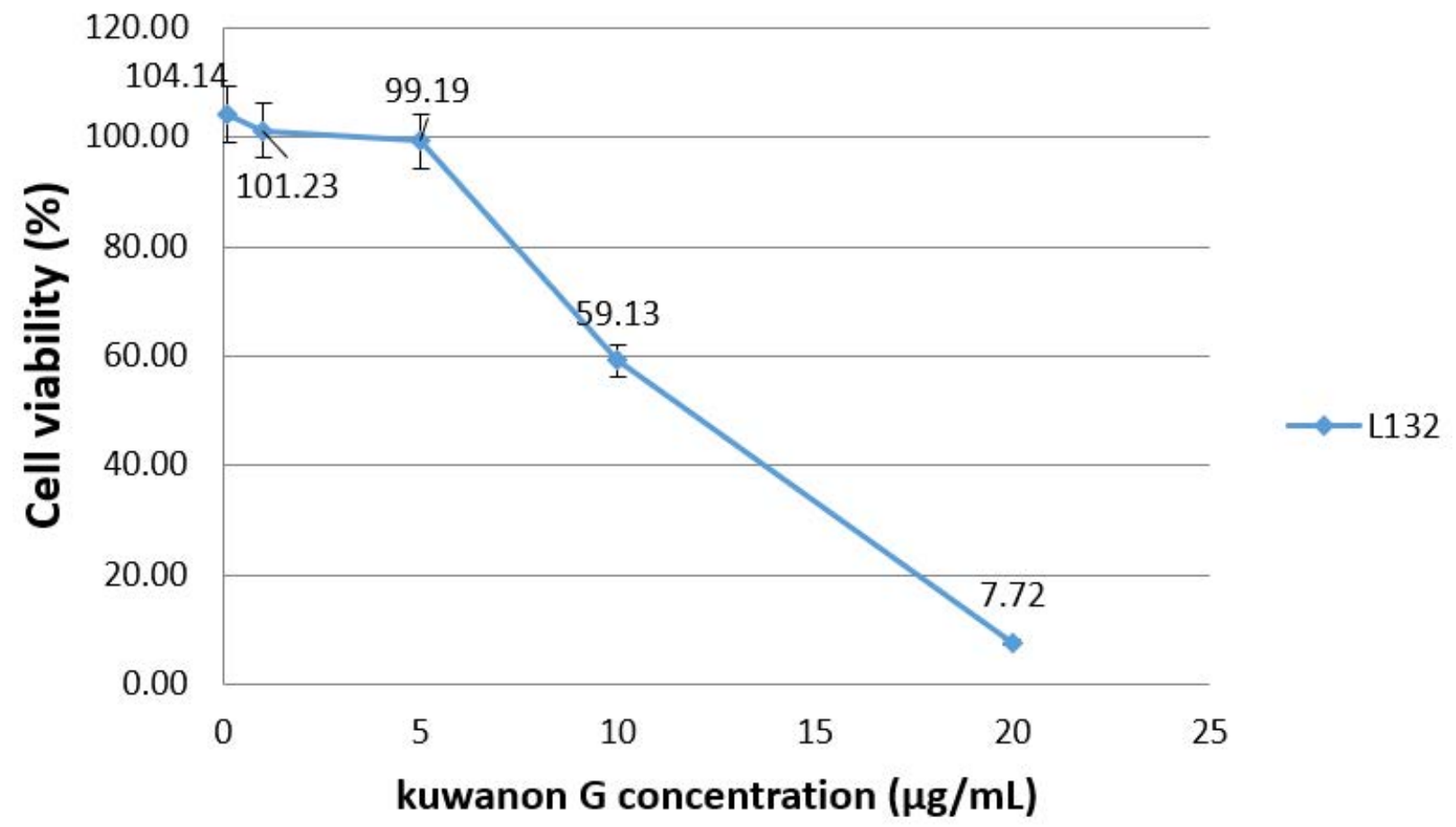

Figure 1. Cytotoxicity of kuwanon G on L-132 cell at $72 \mathrm{~h}$ post-treatment.

\subsection{Screening of Antiviral Activities}

The antiviral activity of stem barks and leaves' hydromethanolic and aqueous extracts are shown in Table 2. 
Table 2. Antiviral activities of stem barks and leaves' aqueous and hydromethanolic extracts on $\mathrm{HCoV}$ 229E and PV1.

\begin{tabular}{|c|c|c|c|c|c|c|}
\hline \multirow{2}{*}{\multicolumn{2}{|c|}{ Vegetal Material }} & \multirow[b]{2}{*}{ Extract } & \multicolumn{2}{|c|}{ HCoV 229E } & \multicolumn{2}{|c|}{ PV1 } \\
\hline & & & $\begin{array}{l}\text { Viral Titer } \\
\quad\left(\log _{10}\right)\end{array}$ & $\begin{array}{l}\text { Inhibition } \\
(\%)\end{array}$ & $\begin{array}{l}\text { Viral Titer } \\
\left(\log _{10}\right)\end{array}$ & $\begin{array}{l}\text { Inhibition } \\
\qquad(\%)\end{array}$ \\
\hline \multirow{6}{*}{$\begin{array}{c}\text { Stem } \\
\text { barks(50 } \\
\mu \mathrm{g} / \mathrm{mL})\end{array}$} & \multirow{2}{*}{ M. alba alba } & $\mathrm{MeOH}$ & $2.16 \pm 0.52$ & 41 & $5.44 \pm 0.10$ & 7 \\
\hline & & $\mathrm{Aq}$ & $2.40 \pm 0.67$ & 35 & $5.67 \pm 0.29$ & 3 \\
\hline & \multirow{2}{*}{$\begin{array}{c}\text { M. alba } \\
\text { rosea }\end{array}$} & $\mathrm{MeOH}$ & $1.98 \pm 0.29$ & 45 & $5.10 \pm 0.36$ & 12 \\
\hline & & $\mathrm{Aq}$ & $2.50 \pm 0.87$ & 36 & $5.61 \pm 0.19$ & 4 \\
\hline & \multirow{2}{*}{ M. rubra } & $\mathrm{MeOH}$ & $2.30 \pm 0.17$ & 37 & $4.96 \pm 0.48$ & 15 \\
\hline & & $\mathrm{Aq}$ & $2.42 \pm 0.54$ & 34 & $5.62 \pm 0.33$ & 3 \\
\hline \multirow{6}{*}{$\begin{array}{l}\text { Leaves }(200 \\
\mu \mathrm{g} / \mathrm{mL})\end{array}$} & \multirow{2}{*}{ M. alba alba } & $\mathrm{MeOH}$ & 0 & 100 & $5.40 \pm 0.17$ & 7 \\
\hline & & $\mathrm{Aq}$ & $1.88 \pm 0.67$ & 48 & $5.61 \pm 0.67$ & 4 \\
\hline & \multirow{2}{*}{$\begin{array}{c}\text { M. alba } \\
\text { rosea }\end{array}$} & $\mathrm{MeOH}$ & $1.05 \pm 0.59$ & 71 & $5.44 \pm 0.10$ & 6 \\
\hline & & $\mathrm{Aq}$ & $2.24 \pm 0.65$ & 39 & 5. $46 \pm 0.24$ & 6 \\
\hline & \multirow{2}{*}{ M. rubra } & $\mathrm{MeOH}$ & $1.19 \pm 0.60$ & 67 & $5.12 \pm 0.67$ & 12 \\
\hline & & $\mathrm{Aq}$ & $2 \pm 0.50$ & 45 & $5.43 \pm 0.23$ & 7 \\
\hline \multicolumn{2}{|c|}{ Negatif control } & & $3.65 \pm 0.17$ & 0 & $5.82 \pm 0.39$ & 0 \\
\hline
\end{tabular}

$\mathrm{MeOH}$ : hydromethanolic extract; Aq: aqueous extract. Each value in the table is represented as mean $\pm \mathrm{SD}(\mathrm{n}=3)$.

The viral titer is expressed as mean $\log _{10} \pm \mathrm{SD}$.

Concerning the picornavirus (HPeV1, $\mathrm{HPeV} 3$, and Echo11) infections, no significant inhibition of the viral infection has been noticed at the tested concentration (data not shown). For example, aqueous and hydromethanolic stem bark extracts led to a viral titer $\left(\log _{10}\right.$ CCID50/mL) from 4.96 (M. rubra) to 5.67 (M. alba var. alba) after PV1 infection, as shown in Table 2. The inhibition percentage ranged from 2.67 (M. alba var. alba) to 14.86 (M. rubra).

Considering HCoV 229E, the inhibition percentages of viral infectivity ranged from $34 \%$ to $36 \%$ for the aqueous stem bark extracts and from $37 \%$ to $45 \%$ for the hydromethanolic stem bark extracts. Hydromethanolic stem barks extracts of M. alba var rosea led to production of the lowest HCoV 229E titer of 1.98 and inhibited viral infectivity down to $45 \%$. With aqueous extracts, the highest inhibition percentage is $36 \%$ for M. alba var. rosea.

Aqueous and hydromethanolic leaves' extracts led to a viral titer $\left(\log _{10} \mathrm{CCID} 50 / \mathrm{mL}\right)$ ranging from 0.00 (M. alba var. alba) to 2.24 (M. alba var rosea). As for stem bark extracts, inhibition percentages of the hydromethanolic leaves' extracts seem higher than the inhibition percentages of the aqueous extracts. Indeed, inhibition percentages of the hydromethanolic leaves' extracts ranged from $67 \%$ (M. rubra) to $100 \%$ (M. alba var. alba) when inhibition percentages of the aqueous leaves' extracts ranged from $38.54 \%$ (M. alba var rosea) to $48 \%$ (M. alba var. alba).

All the studied extracts were more active against coronavirus, which is an enveloped virus, than against nonenveloped picornaviruses.

Thus, Figure 2 shows that the cytopathogenic effect (CPE) is strongly reduced after $200 \mu \mathrm{g} / \mathrm{mL}$ of leaves' methanolic extract of Morus alba var. alba and after $50 \mu \mathrm{g} / \mathrm{mL}$ of steam barks' methanolic extract of Morus alba var. rosea. These results are relevant with the calculated inhibition percentages.

\subsection{Antiviral Activities of Kuwanon $G$}

Given that all the Morus extracts were more active against the coronavirus, the antiviral activity of kuwanon G, present in the extracts, was evaluated on HCoV 229E. Figure 3 shows the CPE of HCoV $229 \mathrm{E}$, after $72 \mathrm{~h}$, on L-132 cells treated with several concentrations of kuwanon G. Concentrations of 0.1 and $1 \mu \mathrm{g} / \mathrm{mL}$ do not reduce the CPE, which remains respectively at $79 \%$ and $76 \%$ when the control (infected, nontreated cells) is $81 \%$. 

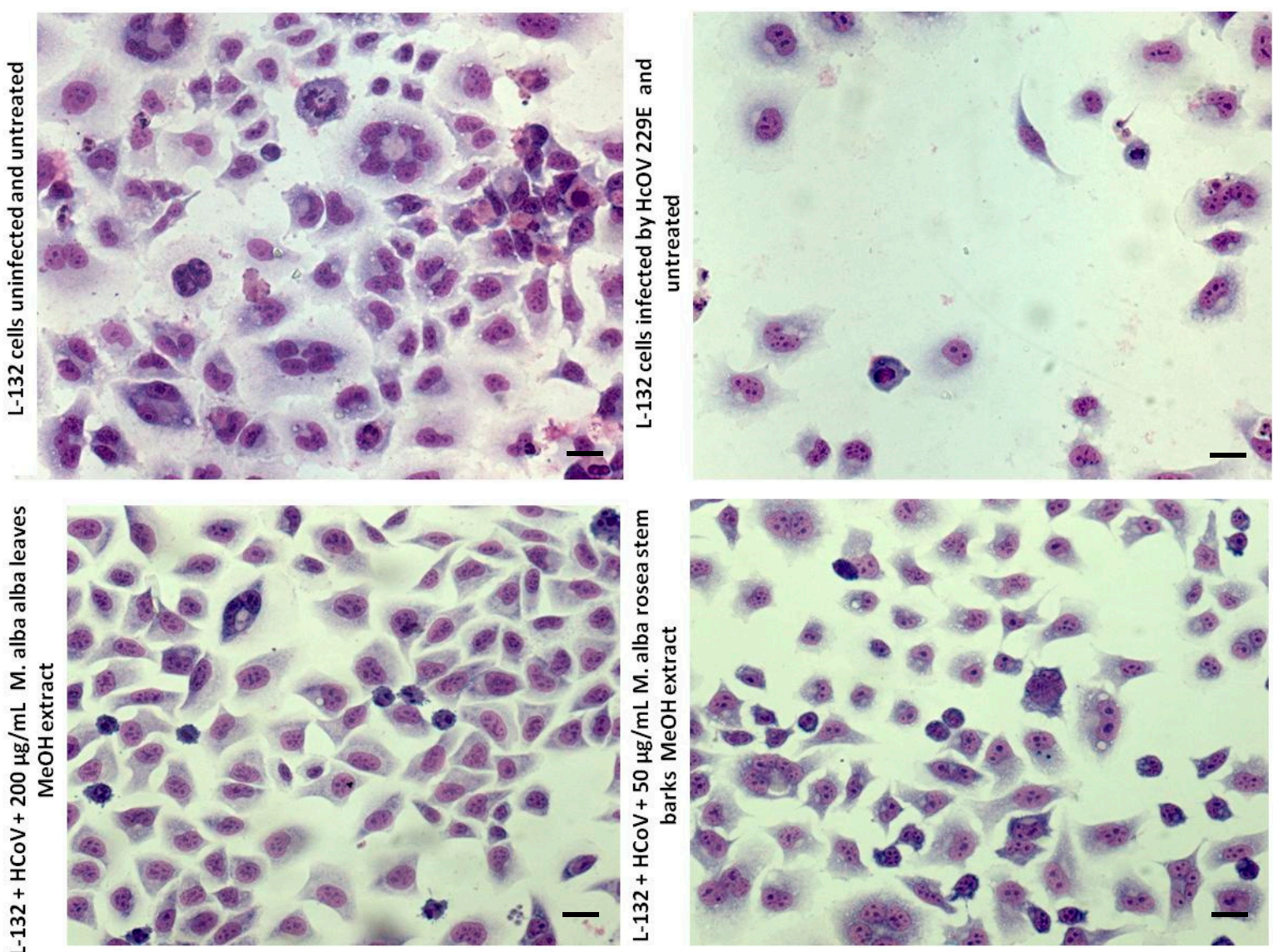

Figure 2. Human coronavirus $(\mathrm{HCoV}) 229 \mathrm{E}$ cytopathogenic effects observed with hydromethanolic extracts of Morus alba var. alba leaves and Morus alba var. rosea stem barks. Scale bar, $20 \mu \mathrm{m}$.

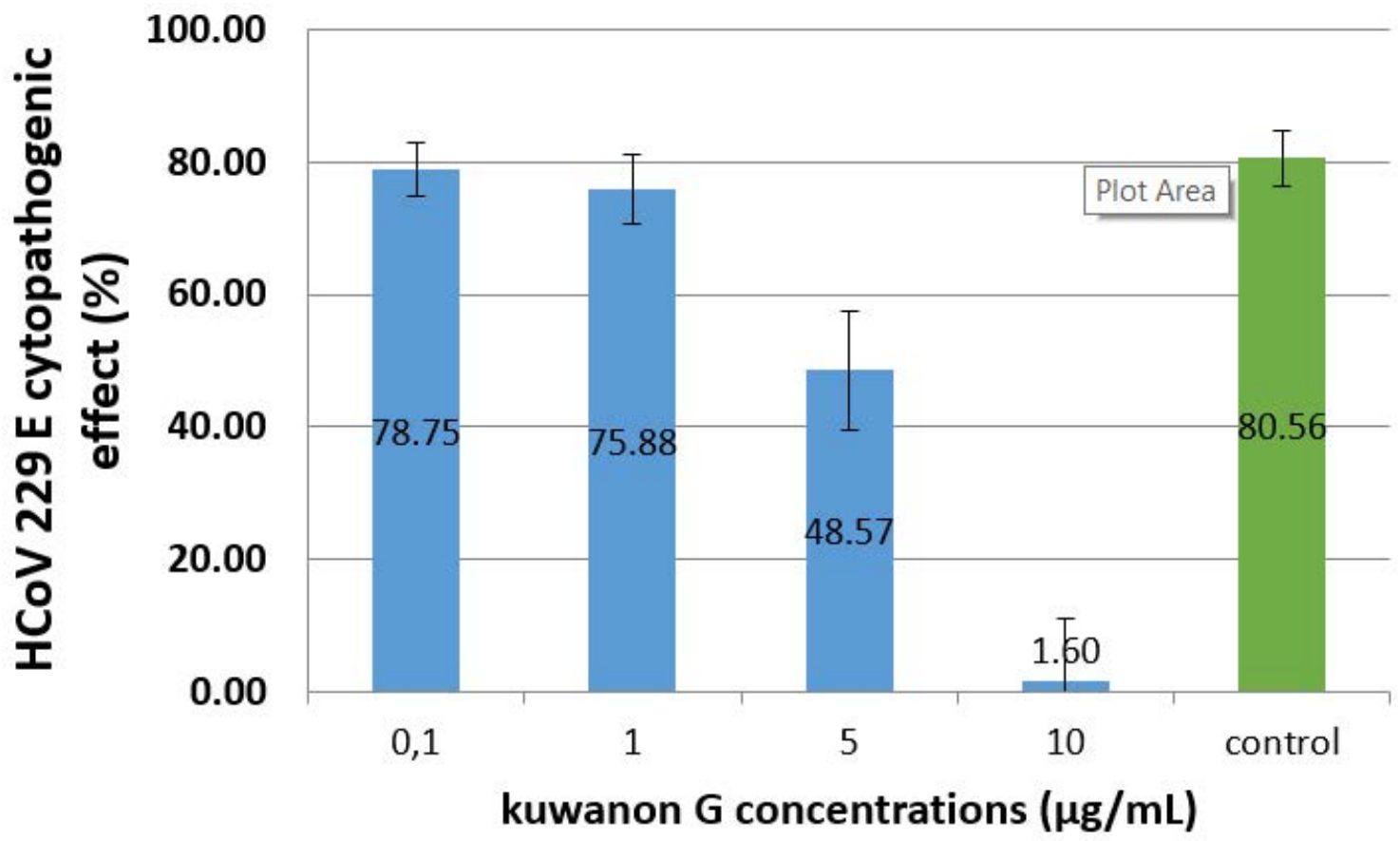

Figure 3. Evaluation of $\mathrm{HCoV} 229 \mathrm{E}$ cytopathogenic effects on L-132 cells (MOI $=1)$ in the presence of kuwanon $\mathrm{G}$ at different concentrations between 0.1 and $10 \mu \mathrm{g} / \mathrm{mL}$ at $72 \mathrm{~h}$ post-infection.

However, a concentration of $10 \mu \mathrm{g} / \mathrm{mL}$ strongly reduced the CPE down to $2 \%$. 
The drug concentrations needed to inhibit $50 \%$ of the viral CPE (EC50), as well as to induce $50 \%$ cell death (CC50), were determined in the 72-h assays. Kuwanon G antiviral activities (EC50) for the different MOI $(0.01,0.1$, and 1) ranged from $0.11 \pm 0.13 \mu \mathrm{g} / \mathrm{mL}$ to $0.56 \pm 0.2 \mu \mathrm{g} / \mathrm{mL}$ and $5.61 \pm 0.67 \mu \mathrm{g} / \mathrm{mL}$, while the value obtained for CC50 was $9.45 \pm 0.55 \mu \mathrm{g} / \mathrm{mL}$. The resulting selectivity index (SI) (the ratio of CC50 to EC50) for kuwanon G was 86.73, 17.04, and 1.70, respectively (Figure S1).

\section{Discussion}

The ethnopharmacological approach has the potential to identify new antiviral compounds, yet relatively few antiviral screenings of plant ethnomedicines have been conducted.

The 50\% cytotoxic concentrations (CC50) of studied extracts of the three Morus species were different between the aqueous and hydromethanolic extracts and between the leaves and stem barks' extracts. The fact that methanolic extracts seem to be more toxic indicates that the organic fraction may contain more cytotoxic compounds. Further analyses of the extracts could provide more information about these compounds.

It also appears that extracts can exert antiviral effects in vivo, but this effect may not be detected by in vitro assays because of the extremely low concentrations of extracts tolerated by the cells in the artificial system [22]. It is also possible that the total extract contains synergistic compounds that are necessary to ensure an antiviral activity.

Our results suggest that hydromethanolic extracts are more efficient in inhibiting the $\mathrm{HCoV} 229 \mathrm{E}$ infection in L-132 cells.

Indeed, aqueous and hydromethanolic stem barks and leaves' extracts showed lower antiviral activity towards picornaviruses compared to $\mathrm{HCoV} 229 \mathrm{E}$ at the tested concentrations. Certainly, hydromethanolic leaves' extracts showed the best antiviral activity against enveloped viruses, especially the M. alba var. alba extract, which completely eliminated the HCoV 229E infection (Figure 2). M. alba var. rosea stem barks' hydromethanolic extract was also the most active against HCoV 229E.

The better inhibitions against the enveloped virus (HCoV 229E) than the nonenveloped viruses (PV 1, HPeV 1, HPeV 3, and Echo 11) suggest that the active components might inhibit the interaction between the binding sites of the virus to the host cells by inhibiting a ligand of the viral envelope. The interaction between the virus envelope and the extracts could be related to the binding of phytochemical phenolic compounds with the protein coat of the virus and the viral attachment to the host cells.

In view of the significant proportion of plant extracts that have yielded positive results in these screenings, it seems reasonable to conclude that there are probably numerous types of antiviral compounds (like kuwanons, mulberrofuran, or oxyresveratrol) in these materials. Further characterization of the active ingredients of these plants might reveal more useful compounds $[15,16]$.

A number of medicinal plants have been reported to contain compounds possessing strong antiviral activity [2]. It has been demonstrated that two prenylated flavonoids, namely leachinone $G$ and mulberroside $C$, from seven known compounds isolated from $M$. alba root barks, were active principles for anti-HSV-1 activity, presenting $50 \%$ inhibitory concentrations of $1.6 \mu \mathrm{g} / \mathrm{mL}$ and $75.4 \mu \mathrm{g} / \mathrm{mL}$, respectively [14]. Moracine $\mathrm{P}$, moracine $\mathrm{O}$, moracine $\mathrm{M}$, and mulberrofurane $\mathrm{K}$, 2-arylbenzofuran derivatives isolated from root barks' ethyl acetate fraction, had a strong activity against the hepatitis $C$ virus [15]. In previous works, phenolic acids and flavonol glycosides were identified in mulberry leaves [23]. Caffeic acid and chlorogenic acid were the major identified phenolic acids which were studied for their antiviral activities. Caffeic acid potentially inhibited the proliferation of HSV2 and adenovirus3 (ADV3) at, respectively, EC50 of $87.3 \mu \mathrm{g} / \mathrm{mL}$ and $14.2 \mu \mathrm{g} / \mathrm{mL}$ [24], whereas chlorogenic acid possessed the strongest anti-ADV-11 activity $(\mathrm{EC} 50=13.3 \mu \mathrm{g} / \mathrm{mL})$. Chlorogenic acid and caffeic acid were potential inhibitors of hepatitis B virus multiplication, reducing the number of viral particles in the serum by blocking DNA synthesis [25].

The study presented in [4] highlighted the antiviral activity of a Morus rotunbiloba infusion against the herpes simplex virus type 2 (HSV2), and they determined a 50\% inhibitory concentration of $0.52 \mu \mathrm{g} / \mathrm{mL}$. Methanolic extracts of some Thai medicinal plants have been reported to 
exhibit anti-HSV1 [3] and anti-HSV 2 [1] activities by inactivating the viral infections on the plaque-reduction assay.

Concerning kuwanon $\mathrm{G}$, our results simultaneously show that a dose of $5 \mu \mathrm{g} / \mathrm{mL}$ is not toxic for L-132 cells (viability at $99.19 \%$ ) when the same dose is able to reduce the HCoV 229E CPE from $80.56 \%$ to $48.57 \%$.

According to the authors of [2], flavonoids were able to block the virus RNA synthesis, and the antiviral activity appeared to be associated to these compounds, and hydroxylation at the 3-position is apparently a prerequisite for antiviral activity. For example, quercetin reduced viral particle productions of herpes simplex virus type 1 , poliovirus type 1 , parainfluenza virus type 3 , and respiratory syncytial virus [26].

The different molecules present in the extracts could act with synergy on different stages of the virus replication cycle (endocytosis, uncoating, replication, etc.). It could interact with the membrane viral glycoproteins (proposed as the binding site of some viruses) or with specific cell receptors, thereby blocking viral entry into the host cell or inhibiting viral replication [27].

The exploration of the antiviral mechanisms of Morus extracts and, particularly, of kuwanon G would need an in-depth molecular investigation like genome quantification, gene expression analysis, and protein expression. Further research on compounds like kuwanon $\mathrm{G}$ can result in a more potent inhibitor able to stop the newly emerged SARS-CoV-2 strain of HCoV.

\section{Materials and Methods}

\subsection{Plant Material}

Morus alba var. alba, Morus alba var. rosea, and Morus rubra leaves and stem bark were harvested during May 2011 from mulberry trees in Gabes Province (Southern Tunisia: $33^{\circ} 40^{\prime} \mathrm{N}, 10^{\circ} 15^{\prime} \mathrm{E}$ ). The plant was identified and collected by Dr I. Thabti from the Arid Land Institute, Tunisia (Institut des Régions Arides: IRA), and voucher specimens (VS1-MAA2011, VS2-MAR2011, and VS3-MR2011) were deposited at the Herbarium of Arid Land Institute. Plant material was collected, immediately put in aluminum foil on ice and away from direct sunlight, and stored at $-20^{\circ} \mathrm{C}$ in the laboratory upon arrival. Then, the plant material was washed with distilled water and lyophilized. The dried materials were ground into powder with a blender and stored in an air-tight container at $-20^{\circ} \mathrm{C}$ until use.

\subsection{Aqueous and Hydromethanolic Extracts Preparation}

Approximately $3 \mathrm{~g}$ of lyophilized leaves and stem barks of Morus alba var. alba, Morus alba var. rosea, and Morus rubra L. were extracted with 100-mL water/methanol and 50/50 (MeOH 50\%) in a water bath at $80^{\circ} \mathrm{C}$ for $15 \mathrm{~min}$. The same amount $(3 \mathrm{~g}$ ) of lyophilized leaves and stem barks were extracted with water. Respective $\mathrm{MeOH} 50 \%$ and aqueous phases were filtered and concentrated under vacuum to give the crude extracts, which were lyophilized and stored at $-20^{\circ} \mathrm{C}$ prior to experimentation.

\subsection{Mass Spectrometry Analysis}

GC-MS identification of alkaloid extracts and a quantitative GC-MS analysis by using external standards (kuwanon $\mathrm{G}$ ) were performed as previously reported by the authors of [28]. The quoted method was used to compare the contents of the different leaves and stem barks' extracts of the three studied species of Morus spp.

For identification, the LC system consisted of an U3000-Dionex apparatus (Thermo Fisher Scientific, Waltham, MA, USA) with an injector comprising a $5-\mu \mathrm{L}$ loop. Two microliters of sample were injected. The analytical column used was an HILIC mixed mode- $1(100 \mathrm{~mm} \times 2.1 \mathrm{~mm})$ and eluted at a flow rate of $200 \mu \mathrm{L} / \mathrm{min}$ using a gradient ranging from $98 \%$ solvent $\mathrm{B}$ to $80 \%$ solvent $\mathrm{B}$ in a time span of 40 min. Solvent A consisted of water with $10-\mathrm{mM}$ ammonium acetate, and solvent B consisted of pure acetonitrile. The ESI-HRMS was a microTOFQ ${ }^{\mathrm{TM}}$ (Bruker Daltonics, Bruker, Bremen, Germany) apparatus. The LC coupled with high-resolution mass spectrometry (ESI/QTOF, Bruker Daltonics, 
Bruker, Bremen, Germany) was used in order to determine the accuracy mass of compounds in the sample extracts. The identification of compounds was performed by comparing the measured molecular mass with the calculated values $\pm 10 \mathrm{mDa}$. The analysis was performed in positive mode, and the compound was confirmed by auto-MSMS experiment when the intensity was higher than $1 \times 10^{4}$. This system was able to detect the compounds in amounts lower than $1 \mu \mathrm{g} / \mathrm{mL}$. We used a compass for the otof series 1.7 software (Bruker Daltonics, Bruker, Bremen, Germany, 2013), including otof Control 3.4, for acquisition and DataAnalysis 4.2 for data processing.

To quantify, we used an LC Systeme Advance ${ }^{\mathrm{TM}}$ (Bruker Daltonics, Bruker, Bremen, Germany) coupled with an ESI-TQ Evoq ${ }^{\text {TM }}$ (Bruker Daltonics, Bruker, Bremen, Germany). The analytical column used was an InfinityLab Poroshell 120 EC-C18 column $(50 \mathrm{~mm} \times 30 \mathrm{~mm})$ and eluted at a flow rate of $800 \mu \mathrm{L} / \mathrm{min}$, using a gradient ranging from $5 \%$ solvent B to $99 \%$ solvent B in a time span of $40 \mathrm{~min}$. Solvent A consisted of water with 1\% of formic acid, and solvent B consisted of pure acetonitrile. Kuwanon $\mathrm{G}$ was detected by MRM mode at $20 \mathrm{eV}$ with one quantifying transition $693>203$ and two qualifying transitions $693>355$ and $693>421$. LCMS control and data processing was performed by MS Workstation 8.2.1. (Bruker Daltonics, Bruker, Bremen, Germany, 2016).

\subsection{Antiviral Activity}

\subsubsection{Cytotoxicity Assay}

The cytotoxicity of hydromethanolic and aqueous extracts of Morus alba var. alba, Morus alba var. rosea, and Morus rubra was evaluated in human embryonic pulmonary epithelial cells: L-132 cell line (ATCC CCL-5), according to the MTT assay, as proposed by the authors of [29]. The cells were grown in Eagle's minimum essential medium (MEM) (Sigma-Aldrich, St Quentin Fallavier, France) supplemented with $10 \%$ of heat-inactivated fetal bovine serum (FBS) (Sigma-Aldrich, St Quentin Fallavier, France).

To test the biological activity, the dried, crude extracts were dissolved in MEM complemented with 2\% heat-inactivated fetal bovine serum (FBS) and dimethyl sulfoxide $2 \%$ (DMSO, Sigma-Aldrich, St Quentin Fallavier, France) to concentrations of $50 \mu \mathrm{g} / \mathrm{mL}$ (stem bark extracts) or $200 \mu \mathrm{g} / \mathrm{mL}$ (leaves' extracts).

The assays were performed in triplicate using 96-well flat-bottom tissue culture plates. One-hundred microliters of increasing concentrations from 9.76 to $5000 \mu \mathrm{g} / \mathrm{mL}$ of plant extracts were added to the monolayers of L-132 cells at $80 \%$ confluence. The plates were then incubated at $37^{\circ} \mathrm{C}$ in a $\% \mathrm{CO}_{2}$ atmosphere. After $72 \mathrm{~h}$, the supernatants were removed, and the wells were washed with phosphate-buffered saline (PBS). Ten microliters of MTT ( $5 \mathrm{mg} / \mathrm{mL}$, in PBS) were added to each well, and the plates were incubated for $4 \mathrm{~h}$ at $37^{\circ} \mathrm{C}$. Then, $100 \mu \mathrm{L}$ of sodium dodecyl sulfate (SDS) $(100 \mu \mathrm{g} / \mathrm{mL}$, in PBS) were added to the wells to solubilize the MTT crystals. The plates were incubated for $4 \mathrm{~h}$ in $37^{\circ} \mathrm{C}$. The absorbance was read at $570 \mathrm{~nm}$ using a 96-well plate ELISA reader (MultiSkan GO, Thermo Scientific, Saint Herblain, France), and the 50\% cytotoxic concentration (CC50) was then calculated as previously described [30].

To confirm the results obtained with the MTT assay, the monolayers were also observed microscopically for estimation of the CPE (i.e., rounding and other marked morphologic changes with respect to control cells).

\subsubsection{Viruses Production}

Human coronavirus HCoV 229E (ATCC VR 740) and single-stranded RNA viral strains (HPEV-1, HPEV-3, PV1-Lsc/2ab, and Echo11) were propagated in the L-132 cell line (ATCC CCL-5).

For virus titration, the cells $\left(10^{4}\right.$ cells/well) grown in 96-well tissue culture plates were incubated for $72 \mathrm{~h}$ at $33{ }^{\circ} \mathrm{C}$ in a $5 \% \mathrm{CO}_{2}$ atmosphere with serial 10-fold diluted virus suspensions. Then, infected wells were recorded. Viral titers and CCID 50 (50\% cell culture infectious doses) were calculated using 
the Reed and Muench method [31]. All plates were observed daily for a cytopathic effect (CPE), and the estimation of the viral titer was made on the third day.

The virus titers $(\log 10 \mathrm{CCID} 50 / \mathrm{mL})$ were 3.65 for HCoV 229E and 5.82 for PV1 (the dilution of virus required for CCID50/mL lytic effect $50 \%$ of the inoculated cultures).

\subsubsection{Antiviral Activity Assay of the Extracts}

The antiviral activity of mulberry aqueous and hydromethanolic leaves and stem barks' extracts were evaluated in vitro by the CPE method using 96-well flat-bottom tissue culture plates and a crystal violet $(\mathrm{CV})$ staining test. In these assays, the concentrations used were $50 \mu \mathrm{g} / \mathrm{mL}$ for aqueous or hydromethanolic stem barks' extracts and $200 \mu \mathrm{g} / \mathrm{mL}$ for aqueous or hydromethanolic leaves' extracts. These concentrations have been chosen according to the cytotoxic assay and are much lower than the determined CC50 on the L-132 cells.

The virus suspension produced as described above was diluted to 1:10 in extract solutions before infection.

Then, $100 \mu \mathrm{L} /$ well of culture medium, containing each extract (at its respective concentration) supplemented with viral suspension, were added to confluent monolayer cells. Controls consisted of culture medium alone, culture medium with extract, and untreated noninfected cells. Furthermore, all tests were compared with plates consisting of untreated infected cells.

All assay plates were incubated at $33{ }^{\circ} \mathrm{C}$ in a $5 \% \mathrm{CO}_{2}$ atmosphere incubator for $72 \mathrm{~h}$. All wells were then observed and scored for viral-induced $\mathrm{CPE}$ under an inverted light microscope and by the CV method, as previously described, to evaluate cell viability [29]. Briefly, the cells were fixed for $5 \mathrm{~min}$ with $3.7 \%$ of paraformaldehyde, then stained for $30 \mathrm{~min}$ with $0.1 \%$ of crystal violet in $1 \%$ ethanol. Finally, monolayers were washed 2 times with PBS; then, quantification of the cells was obtained by an absorbance measurement $(540 \mathrm{~nm})$ after dissolution in 100 microliters of $50 \%$ methanol in PBS. Cytopathogenic effect was calculated as a percentage of infected cells compared to noninfected control cells.

The viral titer and the inhibition percentage of the viral infection were determined as follows:

$$
\text { Ivi }=[(\text { VTuc }- \text { VTtc }) / V T t c] \times 100
$$

with Ivi: inhibition percentage of the viral infection, VTuc: virus titer in the untreated control, and VTtc: virus titer in the treated control.

\subsubsection{Antiviral Activity Assay of Kuwanon G}

Prior to the antiviral tests, the cytotoxicity of kuwanon $\mathrm{G}$ was evaluated as described in 4.4.1. The tested concentrations ranged from 0 to $20 \mu \mathrm{g} / \mathrm{mL}$. The results were calculated after 3 independent experiments, and 4 replicates for each concentration were tested. The cells were then incubated for $24 \mathrm{~h}$ at $37^{\circ} \mathrm{C}$. On the day of infection, dilutions of kuwanon G (Biosynth ${ }^{\circledR}$ carbosynth, CAS No 75629-19-5) from 0.1 to $10 \mu \mathrm{g} / \mathrm{mL}$ were prepared in the culture medium, containing $2 \%$ of FBS. These concentrations have been chosen according to the kuwanon G cytotoxicity assay. Cascade dilutions of the HCoV $229 \mathrm{E}$ virus were prepared for each kuwanon $\mathrm{G}$ dilution in order to test the virus at a multiplicity of infections (MOIs) equal at 1, 0.1, and 0.01, and wells were incubated with the virus/kuwanon $\mathrm{G}$ mix. Each test was reproduced in 8 identical wells. The plates were incubated for $72 \mathrm{~h}$ at $33^{\circ} \mathrm{C}$. The analysis of the wells was performed by microscopic observation of the cytopathogenic effect of HCoV 229E in the presence and absence of kuwanon $\mathrm{G}$ and after staining of the cell monolayers with crystal violet, as previously described.

\subsection{Statistical Analysis}

All tests were carried out in triplicate, and the results were presented as means \pm SD. Statistical analysis was performed using Microsoft Excel 2010 (Microsoft Corp., Redmond, WA, USA, 2010) and 
GraphPAD Prism software (San Diego, CA, USA, 2007). A Wilcoxon test was performed to compare the data. Statistical significance was defined as $p<0.05$.

\section{Conclusions}

Given the pressing need for new antiviral agents and the limitations of in vitro antiviral testing for such agents, the results of this screening were promising. The elucidation of the role of active constituents in the leaves and stem barks of Morus spp. may provide useful leads in the development of antiviral therapeutics. The results of the present investigation provide further evidence of the importance of ethnopharmacology as a guide to the screening for biologically active plants materials in the context of new viral emergencies and resistances.

Supplementary Materials: The following are available online. Figure S1: Normalized antiviral effects of kuwanon G on L-132 cells infected with HCoV 229E (2 independent experiments; 8 replicates).

Author Contributions: Conceptualization, I.T. and M.V.; methodology, M.V.; validation, S.P. and M.V.; formal analysis, I.T., S.P., F.D., and M.V.; investigation, I.T., S.P., S.F., F.D., B.W., T.K., W.E., A.A., and M.V.; writing-original draft preparation, Q.A., I.T., and M.V.; writing - review and editing, Q.A., I.T., S.P, A.R., F.D., and M.V.; supervision, M.V.; project administration, M.V.; and funding acquisition, M.V. All authors have read and agreed to the published version of the manuscript. Authorship is limited to those who have contributed substantially to the work reported.

Funding: This research was supported by CNRS, Université de Lorraine, Institut Jean Barriol, ADRESSE association and by Erasmus + funds.

Acknowledgments: The authors would like to acknowledge PR. Raphael Duval for participating in the initiation of this collaboration.

Conflicts of Interest: The authors declare no conflicts of interest. The funders had no role in the design of the study; in the collection, analyses, or interpretation of data; in the writing of the manuscript; or in the decision to publish the results.

\section{References}

1. Wetprasit, N.; Threesangsri, W.; Klamklai, N.; Chulavatnatol, M. Jackfruit lectin: Properties of mitogenicity and the inhibition of herpesvirus infection. Jpn. J. Infect. Dis. 2000, 53, 156-161.

2. Jassim, S.; Naji, M. Novel antiviral agents: A medicinal plant perspective. J. Appl. Microbiol. 2003, 95, $412-427$. [CrossRef] [PubMed]

3. Lipipun, V.; Kurokawa, M.; Suttisri, R.; Taweechotipatr, R.; Pramyothin, P.; Hattori, M.; Shiraki, K. Efficacy of Thai medicinal plant extracts against herpes simplex virus type 1 infection in vitro and in vivo. Antivir. Res. 2003, 60, 175-180. [CrossRef]

4. Patharakorn, T.; Talawat, S.; Promboon, A.; Wetprasit, N.; Ratanapo, S. Antimutagenicity and Anti-HSV-2 Activity of Mulberry Tea (Morus rotunbiloba Koidz). Kasetsart J. (Nat. Sci.) 2010, 44, 5.

5. Atmar, R.L.; Piedra, P.A.; Patel, S.M.; Greenberg, S.B.; Couch, R.B.; Glezen, W.P. Picornavirus, the Most Common Respiratory Virus Causing Infection among Patients of All Ages Hospitalized with Acute Respiratory Illness. J. Clin. Microbiol. 2011, 50, 506-508. [CrossRef] [PubMed]

6. Monto, A.S.; Fendrick, A.M.; Sarnes, M.W. Respiratory illness caused by picornavirus infection: A review of clinical outcomes. Clin. Ther. 2001, 23, 1615-1627. [CrossRef]

7. Watanabe, K.; Hirokawa, C.; Tazawa, T. Seropositivity and epidemiology of human parechovirus types 1, 3 , and 6 in Japan. Epidemiol. Infect. 2016, 144, 3451-3460. [CrossRef] [PubMed]

8. Ramshaw, R.E.; Letourneau, I.D.; Hong, A.Y.; Hon, J.; Morgan, J.D.; Osborne, J.C.P.; Shirude, S.; Van Kerkhove, M.D.; Hay, S.I.; Pigott, D.M. A database of geopositioned Middle East Respiratory Syndrome Coronavirus occurrences. Sci. Data 2019, 6, 318. [CrossRef]

9. Michaelis, M.; Geiler, J.; Naczk, P.; Sithisarn, P.; Leutz, A.; Doerr, H.W.; Cinatl Jr, J. Glycyrrhizin Exerts Antioxidative Effects in H5N1 Influenza A Virus-Infected Cells and Inhibits Virus Replication and Pro-Inflammatory Gene Expression. PLoS ONE 2011, 6, e19705. [CrossRef] 
10. Cinatl, J.; Morgenstern, B.; Bauer, G.; Chandra, P.; Rabenau, H.; Doerr, H.W. Glycyrrhizin, an active component of liquorice roots, and replication of SARS-associated coronavirus. Lancet 2003, 361, 2045-2046. [CrossRef]

11. Shen, L.; Niu, J.; Wang, C.; Huang, B.; Wang, W.; Zhu, N.; Deng, Y.; Wang, H.; Ye, F.; Cen, S.; et al. High-throughput screening and identification of potent broad-spectrum inhibitors of coronaviruses. J. Virol. 2019, 93, e00023-19. [CrossRef] [PubMed]

12. Gorbalenya, A.E.; Baker, S.C.; Baric, R.S.; de Groot, R.J.; Drosten, C.; Gulyaeva, A.A.; Haagmans, B.L.; Lauber, C.; Leontovich, A.M.; Neuman, B.W.; et al. Severe acute respiratory syndrome-related coronavirus: The species and its viruses-a statement of the Coronavirus Study Group. bioRxiv 2020. Available online: https://www.biorxiv.org/content/10.1101/2020.02.07.937862v1.full.pdf (accessed on 19 February 2020).

13. Momattin, H.; Al-Ali, A.Y.; Al-Tawfiq, J.A. A Systematic Review of therapeutic agents for the treatment of the Middle East Respiratory Syndrome Coronavirus (MERS-CoV). Travel Med. Infect. Dis. 2019, 30, 9-18. [CrossRef] [PubMed]

14. Du, J.; He, Z.D.; Jiang, R.W.; Ye, W.C.; Xu, H.X.; Pui-Hay But, P. Antiviral flavonoids from the root bark of Morus alba L. Phytochemistry 2003, 62, 1235-1238. [CrossRef]

15. Lee, H.Y.; Yum, J.H.; Rho, Y.K.; Oh, S.J.; Choi, H.S.; Chang, H.B.; Choi, D.H.; Leem, M.J.; Choi, E.J.; Ryu, J.M.; et al. Inhibition of HCV Replicon Cell Growth by 2-Arylbenzofuran Derivatives Isolated from Mori Cortex Radicis. Planta Med. 2007, 73, 1481-1485. [CrossRef] [PubMed]

16. Wei, H.; Zhu, J.J.; Liu, X.Q.; Feng, W.H.; Wang, Z.M.; Yan, L.H. Review of bioactive compounds from root barks of Morus plants (Sang-Bai-Pi) and their pharmacological effects. Cogent Chem. 2016, 2, 1212320. [CrossRef]

17. Zeng, Q.; Chen, H.; Zhang, C.; Han, M.; Li, T.; Qi, X.; Xiang, Z.; He, N. Definition of Eight Mulberry Species in the Genus Morus by Internal Transcribed SpacerBased Phylogeny. PloS ONE 2015, 10, e0135411. [CrossRef] [PubMed]

18. Chan, E.W.C.; Lye, P.Y.; Wong, S.K. Phytochemistry, pharmacology, and clinical trials of Morus alba. Chin. J. Nat. Med. 2016, 14, 17-30.

19. Dhiman, S.; Kumar, V.; Mehta, C.M.; Gat, Y.; Kaur, S. Bioactive compounds, health benefits and utilisation of Morus spp.-a comprehensive review. J. Hortic. Sci. Biotechnol. 2020, 95, 8-18. [CrossRef]

20. Aelenei, P.; Horhogea, C.M.; Rimbu, G.; Dimitriu, A.C.; Aprotosoaie, A.C.; Miron, A. Morusin and kuwanon G-Promising anti-MRSA agents. Med. Surg. J.-Rev. Med. Chir. Soc. Med. Nat. 2019, 123, 1.

21. Koirala, P.; Seong, S.H.; Zhou, Y.; Shrestha, S.; Jung, H.A.; Choi, J.S. Structure-Activity Relationship of the Tyrosinase Inhibitors Kuwanon G, Mulberrofuran G, and Albanol B from Morus Species: A Kinetics and Molecular Docking Study. Molecules 2018, 23, 1443. [CrossRef]

22. McCutcheon, A.R.; Roberts, E.; Gibbons, E.; Ellis, S.M.; Babiuk, L.A.; Hancock, R.E.W.; Towers, G.H.N. Antiviral screening of British Columbian medicinal plants. J. Ethnopharmacol. 1995, 49, 2. [CrossRef]

23. Thabti, I.; Elfalleh, W.; Hannachi, H.; Ferchichi, A.; Da Graça Campos, M. Identification and quantification of phenolic acids and flavonol glycosides in Tunisian Morus species by HPLC-DAD and HPLC-MS. J. Funct. Foods 2012, 4, 367-374. [CrossRef]

24. Chiang, L.; Chiang, W.; Chang, M.; Ng, L.; Lin, C. Antiviral activity of Plantago major extracts and related compounds in vitro. Antivir. Res. 2002, 55, 53-62. [CrossRef]

25. Wang, G.F.; Shi, L.P.; Ren, Y.D.; Liu, Q.F.; Liu, H.F.; Zhang, R.J.; Li, Z.; Zhu, F.H.; He, P.L.; Tang, W.; et al. Anti-hepatitis B virus activity of chlorogenic acid, quinic acid and caffeic acid in vivo and in vitro. Antivir. Res. 2009, 83, 186-190. [CrossRef]

26. Kaul, T.N.; Middleton Jr, E.; Ogra, P.L. Antiviral effect of flavonoids on human viruses. J. Med. Virol. 1985, 15, 71-79. [CrossRef]

27. WuDunn, D.; Spear, P.G. Initial interaction of herpes simplex virus with cells is binding to heparan sulfate. J. Virol. 1989, 63, 52-58. [CrossRef]

28. Tarakemeh, A.; Azizi, M.; Rowshan, V.; Salehi, H.; Spina, R.; Dupire, F.; Arouie, H.; Laurain-Mattar, D. Screening of Amaryllidaceae alkaloids in bulbs and tissue cultures of Narcissus papyraceus and four varieties of N. tazetta. J. Pharm. Biomed. Anal. 2019, 172, 230-237. [CrossRef]

29. Tada, H.; Shiho, O.; Kuroshima, K.; Koyama, M.; Tsukamoto, K. An improved colorimetric assay for interleukin 2. J. Immunol. Methods 1986, 93, 157-165. [CrossRef] 
30. Fontanay, S.; Grare, M.; Mayer, J.; Finance, C.; Duval, R.E. Ursolic, oleanolic and betulinic acids: Antibacterial spectra and selectivity indexes. J. Ethnopharmacol. 2008, 120, 272-276. [CrossRef]

31. Reed, L.J.; Muench, H. A simple method of estimating fifty percent endpoints. Am. J. Hyg. 1938, $27,493-497$.

Sample Availability: Samples of the compounds are not available from the authors.

(C) 2020 by the authors. Licensee MDPI, Basel, Switzerland. This article is an open access article distributed under the terms and conditions of the Creative Commons Attribution (CC BY) license (http://creativecommons.org/licenses/by/4.0/). 